\title{
CONTAGION (2011) AS A PREDICTION OF A GLOBAL PANDEMIC OF COVID19
}

\author{
SANAA SAEED MERZA \\ Dept. of English, College of Languages, University of Duhok, Kurdistan Region-Iraq
}

(Received: November 9, 2020; Accepted for Publication: January 23, 2021)

\begin{abstract}
ABSRACT
Contagion film (2011) is a fictional account of the spread of a global pandemic MEV-1 virus. It draws attention to a situation potentially similar to that of the recent events of the outbreak of pandemic coronavirus. The study aims at detecting how Contagion chillingly predicted the global pandemic COVID 19 for nearly a decade ago, and how the filmmakers try their best to portray scenes closer to reality than to imagination. The study also aims to shed a light on the racist political discourse of the film that depicts the third world (represented by the communist superpower, China) as an underdeveloped, dictatorial, and dangerous regime compared to the free and advanced regime (represented by the capitalist superpower, America). Contagion assumes that the trade, tourism, and mobility to the third world countries lead to the possibility of spreading horrific epidemics.

The study is divided into three sections. Section one presents a brief study of an apocalyptic and postapocalyptic fiction. Section two sheds a light on Contagion as a prediction of pandemic coronavirus with reference to the racist political discourse that the film conveys. Section three presents a conclusion that there is a possibility of a pandemic that wipes out the human race despite its vulnerability, and the purpose behind portraying China as an endemic place is to authorize America to intervene to maintain global health security by restricting trade and mobility. The study ends with a list of references, in addition to Arabic and Kurdish synopses.
\end{abstract}

KEY WORDS: COVID 19, Coronavirus, Pandemics, Contagion, Communist, Capitalist, Prediction

\section{SECTION ONE}

\subsection{Apocalyptic And Post-Apocalyptic Fiction}

A tymologically, the term "Apocalyptic" is Cderived from the Greek word "apocalypse", "to disclose". It refers to "the last book of the New Testament, The Revelation of St. John" which "tends to present doom- laden visions of the world and sombre and minatory prediction of mankind's destiny (Cuddon, 1998: 48).

In literature, "Apocalypse" refers to "the written expression of the emphases that characterize apocalyptic communities, whether found in standalone compositions known as apocalypses or in sections of material assimilated into other genres of literature" (A. Taylor \& David M. Howard Jr., 2016, 36).

Apocalyptic and post-apocalyptic fiction refers to a type of writing that deals "with the aftermath of a catastrophic event that devastates humanity. The catastrophe can be manmade, such as a nuclear war, or a natural disaster such as an asteroid hitting the Earth or a new plague. There are no limits to what can cause the damage in this genre, as long as it results in the extreme deterioration of quality of life and society as a whole", if "the disaster or catastrophe occurs during the course of the story, then the novel is termed apocalyptic. If the event has already happened, it is post-apocalyptic" (Amanda Pagan, 2019).

Overwhelmingly, the events of this type of fiction revolve around the natural disasters, such as storm and devastating floods, or astronomical, such as resource depletion and a nuclear explosion, or medicinal ones, such as the spread of a virus and defective genes.

In apocalyptic fiction, the writer tries to prevent the event of apocalyptic by dealing with the event itself, its impact and consequences. While in post-apocalyptic fiction, the writer deals with the events that happen after the catastrophe, in which nothing of civilization is left, but remnants of society and technology. In post-apocalyptic fiction, the writer focuses mainly on the surviving of human race (Valerie P Zimbaro, 1996).

Originally, the roots of apocalyptic and the post-apocalyptic elements can be found in the prophetical stories, for example: the biblical 
story of Noah and his ark, which describes the global flood to efface the evilness and replace it with a new world (Norman Cohn, 1999). The Qur'anic story of prophet Lot is another example of apocalyptic and the post-apocalyptic. It exposes how God destructs the two cities Sodom and Gomorrah to wipe out the evilness of their sins of violence and lust, "So We saved him and all of his family, except an old woman, 1 who was one of the doomed. Then We utterly destroyed the rest, pouring upon them a rain of brimstone'. How evil was the rain of those who had been warned! Surely in this is a sign. Yet most of them would not believe." (The Noble Quran, Surah Ash-Shu'ara/ The Poets,2020, 170174).

In literature, apocalyptic can be found in the mythology of Babylonian and Judaic tradition, such as the Epic of Gilgamesh epic written c. 1800 BC. Modern apocalyptic works have emerged during 19th. c. with Lord Byron's Darkness (1816). It is about the apocalyptic end of the world because of the cold, famine, and darkness after the sun is blotted. All people are died, and only one man is survived. The poem becomes a source of writers' inspiration to write many works such as; Thomas Campbell's The Last Man (1824) and Thomas Hood's the Last Man (1826) (Morton D. Paley, 1989).

Mary Shelley's The Last Man (1826), is another example of an apocalyptic fiction. It is about a group of people struggling for survival in a world afflicted with plague (Morton D. Paley, 1989). Richard Jeffreys' novel After London (1885) is a post-apocalyptic novel. It depicts a sudden disaster causes England to be depopulated, the countryside returns to nature and the few survivors return to a medieval lifestyle. H.G. Wells novel, The War of the Worlds (1898) depicts an alien invasion of Earth and the destruction of Victorian England with indestructible weapons.

By $20^{\text {th }} . c$. , apocalyptic and post-apocalyptic fiction becomes more popular. It is widely used to reflect the scenes of annihilation in various fields of life by nuclear weapons, virus, alien invasion, or natural catastrophe. Clarke's Childhood's End (1953) is a science fiction. It is about the coming of aliens to earth and the damage to a planet. In Night of the Living Dead (1968), Dawn of the Dead (1978) and Day of the Dead (1985) films, the director George A. Romero depicts how the outbreak of an unknown pandemic turns people into apocalyptic zombies.
In the Forge of God (1987), Greg Bear portrays the distraction of the earth because of an alien attack. Aliens preserve samples from people and biosphere to be settled on Mars. The film 12 Monkeys (1995) illustrates the remnants of human civilization after the outbreak of a pandemic that kills 99\% of humanity (James Berger, 2000). 28 Days Later film (2002) revolves around a virus that turns anyone infected into a mindlessly violent psychotic. I am legend (2007) is a post-apocalyptic film. It depicts the negative effect of a virus which is originally created to treat cancer in destroying mankind, leaving Neville as the last man in New York. The Impossible film (2012) is about a Spanish tourist Dr. Maria Belon, one of the survivors when the tsunami hits (Rachel Curtis, 2012). World War $Z$ film (2013), depicts the effect of a global pandemic that spreads in China and transmits around the world through trade and travel (Azeez Jasim, 2015).

\section{SECTION TWO \\ 2.1 Contagion (2011) As A Prediction Of Coronavirus}

Contagion (2011) is one of an American pandemic film. It has garnered millions of views recently because it seems to predict and emulate potentially a similar situation during a global pandemic to that of the recent events of COVID 19. In 2019, Warner Bros. has indicated that Contagion which had numbered 270th. in its catalog titles before many years, has jumped to second place, after the outbreak of COVID-19 pandemic (Nicole Sperling, 2020).

Contagion is written by Scott Z. Burns and directed by Steven Soderbergh. It includes many Hollywood stars like Gwyneth Paltrow, Matt Damon, Kate Winslet, Jennifer Ehle, Laurence Fishburne, Marion Cotillard, Jude Law. The director uses the style of "hyperlink cinema" to follow many interacting plot lines and complex narrative structures. He scatters spectators' attention among so many plot lines and characters, including those who work desperately to find a vaccine, the infected victims, the people who scare to have any attachment with any one of them, and the dead because of virus. Scott Z. Burns says he has gotten a load of messages on social media recently. Some of these responses praise him for the medical and scientific accuracy of the film and others accuse him of being one of the Illuminati (Nicole Sperling, 2020). 
W. I. Lipkin, one of the film's consultants, published an article in the New York Times about how he used the glamor of Hollywood to convey important messages about the dangers of the breakout of a global pandemic (Johanna Blakley \& Heesung Shin,2016, 6).

In her article for CNN, Laurie Garrett described the film Contagion as "part fantasy, part reality and totally possible."(Kristen Rogers, 2020, 1). B. Jenkins, the writer and director of Moonlight film says that he watches the film Contagion twice "to see how well it would line up to what is happening right now," and "It was shocking. It felt like I was watching a documentary that has all these movie stars playing real people." (Nicole Sperling, 2020:12).

The screenwriter of Contagion, Scott Burns says that he and all the filmmakers are "trying to tell a story that was credible within the boundaries of scientific understanding, but also illuminate how our world might respond - that is why the poster of the movie says "nothing spreads like fear" (Fran Kritz, 2020: 2).

Stephen Sean Ford, an American director tweeted "For years I said that Contagion is one of the scariest films ever made and now here we are" (Martha Ross, 2020).

\subsubsection{Beginning Of An Outbreak And Its Zoonotic Origine}

Contagion is characterized by the filmmaker's genius which is embodied in his ability to predict events come up in the context of a striking resemblance to what is happening today with the outbreak of COVID 19. Contagion film opens with the coughing of Beth Emhoff (a Gwyneth Paltrow) who becomes an identify case in a pandemic MEV-1 that has originated in Hong Kong, China and killed 26 million around the world in less than a month. The virus MEV-1 is portrayed as a hybrid of influenza and Nipah virus that has appeared in Malaysia, during the 1990s (Kristen Rogers, 2020). While COVID-19 is the result of different viruses. Antoni Wrobel and Donald Benton assert in their study at the Francis Crick Institute that SARS-CoV-2, (the cause of COVID-19) is the result of different viruses merging together and evolving into one virus.

The researchers at the Francis Crick Institute suggest that SARS-CoV-2 has similar structure of the spike protein to that of a bat coronavirus, RaTG13, but the spike of SARS-CoV-2 has a stability and ability to bind on human cells 1,000 times more tightly than the bat virus (Antoni G. Wrobel \& et al., 2020).

In the same context, COVID-19 has originated in Wuhan, China and recorded 40665 438 confirmed cases and 1121843 confirmed deaths around 235 countries, areas or territories with cases from 31, December 2019 to 21 October 2020, 03:00 GMT+3 (World Health Organization, 2020).

The death rate among those infected in the film is more $25 \%$, than the death rate in the current disease.

Contagion portrays the anxiety of people from the escalation of disease and how that disease infects healthy young people, and the elderly alike. Contagion sheds light on a fact that a virus has zoonotic origin, it is initially passed onto the people through unsanitary restaurant as it appears at the end of the film, when a piece of banana is fallen from a wrong bat to be picked up by a wrong pig. Then that pig is taken to restaurant to be slaughtered and cooked by a chef who shakes Beth Emhoff's hands without washing them. Then, Beth Emhoff (Gwyneth Paltrow) becomes the first "index case" or "identified case" (Kristen Rogers, 2020, 2). The host animal can be infected with more than one virus merging together in its body to be transmitted later to humans (Antoni G. Wrobel $\&$ et al., 2020).

Many experts such as Rebecca Katz, the director of the for Global Health Science Center and Security at the University of Georgetown reveals that Contagion is a realistic story, and she often shows "the last few minutes of Contagion to [her] class, to show the interconnectedness between animals, the environment and humans", and she adds if "you cut down trees, it changes the behavior of bats. The bats interact with swine, [which are] being raised for consumption, and humans then interact with infected swine as part of food preparations. This is just one example of how an emerging infectious disease can jump species into humans" (Fran Kritz, 2020: 3). Dr. Glenn Wortmann, the Chief of Infectious Diseases Section at MedStar Washington Hospital Center in Washington asserts that the "film presents a plausible series of events" according to what is known about how viruses are transmitted from animals to humans (Fran Kritz, 3).

In Contagion, bat is the origin of the pandemic virus that begins quietly in Hong Kong and spreads around the world to kill 2.5 
million in the USA and 26 million around the world

Although, the origin of COVID 19 is still mysterious, most of the scientists who study the origin of current coronavirus present many theories about the outbreak of COVID 19, one of these theories is that markets in Wuhan, China are "wet markets", in which animals that may be infected are collected together to be sold either as pets or food. Any transmission of the zoonotic virus to humans will be easily exacerbated by population density, and public transportation. The other theory that is published in Nature Medicine journal is the disease coronavirus has transmitted and circulated from animals to humans in a less lethal form for years before becoming seriously contagious (Kristen Rogers, 2020, 2-3).

The head of infectious diseases at Medstar Hospital, Glenn W. says that, "The film presents a plausible series of events" "based on what we know about how viruses can possibly jump from animals to humans" (Fran Kritz, 2020, 3).

Scientifically, rodents and bats are the most important carriers of the virus, but they do not be infected with it. In zoonotic disease, the animal is often a carrier of the virus, which perhaps transmits through a series of species, to humans (Zi-Wei Ye \& et al., 2020).

\subsubsection{The Role Of Cdc And Eis Organization In Finding Infected People}

When the fictional disease (MEV-1) is suspected in the film, the CDC is cooperating with the EIS organization to send trained infantry soldiers from the Epidemiological Intelligence Service with a staff from EIS to endemic areas to identify infected people. They also check the places that infected people travel, and the people who they contact, and then isolate them in a specific place to control the outbreak. The health care epidemiologist at the Montefiore Health System in New York, Theresa Madaline says that this "is very consistent with standard epidemiologic principles and practices". In the same context, William Hanage, assistance professor of epidemiology at the university of Harvard T.H. says that "[w] hat is accurate is the professionalism and devotion of staff in the EIS at CDC", adding that "[t]hese people are tireless", and he is "truly honored that several of [his] former students went on to serve in EIS. It's also not an especially glamorous job, for all its importance, and Kate Winslet's portrayal captures that" (Kate is a character in the film and she works for EIS organization) (Fran Kritz, 2020, 4).

\subsubsection{The Transmission Speed Of Virus And The Pathway Of The Breakout}

Epidemiologist Theresa Madaline detects that the transmission speed of a virus and some paths appeared in the film are not completely accurate, for example; Beth Emhoff becomes a vector of the disease on the same day that she catches the virus and begins to cough, while, experts say that Emhoff will not necessarily transmit the virus quickly after infection, and it "would take some period of time - at least days - for her to shed the virus from her respiratory tract or saliva"(Fran Kritz, 2020, 4). Amesh Adalja, senior scholar at the Johns Hopkins Center for Health Security says that the virus has to make many copies in the cells of the human body before it attacks the immune system to show symptoms of the disease and start coughing, and this process requires several days.

About coronavirus, Amesh Adalja says that the period of virus transmission is between 5 and 6 days. (Fran Kritz, 2020, 4-5).

Contagion can be used fruitfully to understand the interconnectedness between the body, the surface, and the viral life and how these elements cling onto each other. The term "Fomite" is uncommon, it is used in the epidemiologists' language when they assess the possibility of the outbreak disease. The term "Fomite" is often used in the film by the epidemiologists to refer to the surface that harbors disease if an infected person touches it and then be transmitted to anyone who touches the same surface, for example, a door of elementary school is touched by Beth Emhoff's son, and a touch screen for restaurant orders is touched by Emhoff's server after handing Emhoff's credit card (Fran Kritz, 2020, 4). Just like coronavirus, the spread of MEV-1 in the film is exacerbated by a person touching his face several times, and in between touching objects and surfaces. Therefore, the contact with surfaces must be avoided, the distances between people must be remade, and the necessary precautions must be taken to avoid the spread of lethal zoonotic disease. The film also depicts the inability of the officials to control the disease, and their bemoaning at how people's anxiety has escalated with the escalation of the infections that damage the business and shakes public confidence in experts' advice as is happening today (Deborah P Dixon \& J.P. Jones, 2017: 910). 
Politically, the film subtly conveys a message to decision makers to stoke how a misguided political decision or reckless act can have a devastating effect in a wide, globalized, and interconnected world (Brian Lowry, 2020).

Undoubtedly, whenever disasters and diseases outbreak, the pre-established protocols are ignored due to the dreadful situation and specific discourse is created to affect the public as well as the experts, and politicians. Contagion has an ideological message to the politicians in decision-making processing to study disaster policies before they happen, and take precautions to counter them. Contagion disseminates its discourse through stereotypes, moral guidelines, and rules to depict the relationship between disasters and popular culture. Contagion is one of the important films that teaches experts, doctors, and politicians to be careful about how to deal with real-life issues and events, and this is what the World Health Organization, governments and politicians are trying to do today (Maximiliano E Korstanje \& Geoffrey Skoll, 2015:1-2).

\subsubsection{The Symptoms And Measures}

The other characteristic of the filmmaker's genius appears through the realistic and convincing portrayal of the film's scenes concerning where and how the disease begins and spreads, the symptoms of the disease, and the measures that are taken by the World Health Organization and the governments to contain the disease. Contagion film encourages people to apply what they learn from the film to their real life, as the film conveys somehow detailed medical information to the spectators to help them prevent today's pandemic. For example, the film shows how a mysterious virus transmits quietly from superpower China to the rest of world through touch, and the respiratory system and kills millions of people around the world, while doctors, medical researchers, and the public health officials try to identify, evaluate and contain this apocalyptic epidemic by finding a vaccine to stop it, just like what happens today The film also shows how an infected person of MEV-1 virus has almost similar symptoms to those of COVID-19 disease, such as dyspnea, fever, cough, chest pain, and loss of speech or movement, but there are no seizures or foaming at the mouth (Kristen Rogers, 2020,4-5).

Taking precautions against the virus is an extremely important for healthcare providers and laboratory personnel. Epidemiologist Theresa Madaline reveals that "in some scenes," the health care workers in the movie "wore personal protective equipment, which is what we normally do when caring for a patient who has a potentially transmissible disease". In another example, a nun who takes care patients at the airport dispensary wears gloves, and a mask to protect herself. Glenn Wortmann asserts that "with a large outbreak, it would be difficult for all health care workers to [completely] maintain appropriate infection prevention measures, and I think the film recognizes those gaps" (Fran Kritz, 2020, 6).

The measures that are taken by the World Health Organization, public health officials, governments, and medical and preventive centers in the film are similar to a large extent to those that occur in reality; such as imposing quarantine, wearing medical masks, preventing flying among cities and countries, closing schools and universities, checking temperatures at airports, preventing trade, tourism, and transportation, and banning bars, clubs, and malls. Ultimately, the film shows that those immune to the virus are very rare when only Mitch Imhoff (played by Matt Damon) is found to be immune to the virus, while no reports have emerged from the World Health Organization proving that immune is found to the Corona virus (Kristen Rogers, 2020, 3-5).

Concerning the vaccine, Dr. Allie Hextal, the CDC researcher scientist (played by Jennifer Ehle), asserts that "it can take months, maybe a year, to be able to distribute a vaccine after testing, clinical trials, manufacturing and distribution". However, she becomes able to find the vaccine, while in fact, senior experts on infectious disease assert that a typical vaccine may take 8 to 10 years to be developed. Madaline says that the way vaccine is developed is not realistic when the scientist inoculates herself to test the effectiveness of the vaccine. She says that "[e]fficacy and safety of vaccines must be established in multiple people, not just one person". In a scenario similar to what happened in the movie, health officials and laboratories around the world are trying to take the fast track of this timeframe (Kristen Rogers, 2020,4-6).

\subsubsection{The Inhumation Of The Victims of Virus}

The film shows how victims of MEV-1 virus are buried in mass graves which, as Epidemiologist Madaline asserts "could be used in outbreak settings when the ability to promptly bury the deceased exceeds morgue and funeral 
home capabilities or when burial itself is a highrisk activity for disease transmission" (Fran Kritz, 2020, 6)..Indeed, with the outbreak of coronavirus which is highly infectious, burial practices have been changed. Scientists debate what the "R0" virus, or reproductive rate, is in the film. R0, which rises as the film progresses indicates the average number of infected people. The specialist Hanage says that "[t]he current outbreak has hopefully helped people understand the concept of $\mathrm{R} 0$ a little better", "[f]olks should be able to understand that if people start trying to take precautions to avoid transmission", and "this number might decrease as it did for SARS, which is how it was defeated" (Fran Kritz, 2020, 6-7).

In Contagion, the death rate of MEV-1 virus is estimated to be more than $25 \%$ while the rate of mortality of Covid-19, as of 26th.March is between $1.8 \%$ and $3.4 \%$, according to the centers for diseases control and prevention Socially, civil disturbances tear apart the structure of society, leaving banks and groceries looted. Police appears unable to control the crime, as martial law prohibits travel to stop the spread of the virus. This does not happen in real life, as in the film, but many of us spend weeks separate from friends, family, and places we love, wondering when the epidemic will end, so we can return to life as we knew it (Kristen Rogers, 2020,4-6).

\subsubsection{Contagion As A Message Of Racism}

Contagion on the other hand, sheds light on a racist discourse that the first world represents the democracy, safety, and scientific and medical development, while the third world represents a source of dictatorship, backwardness, and diseases. It depicts that safety exists only in the first world. The transmission between the third world and the first world leads to disseminate disease in the first world, and this has brought back to the surface the old political tensions between the first and third worlds (US and Mexico) when a virus called "Spanish flu" has spread at the end of the First World War. US and many industrial countries have canceled travel and trade with Mexico as they do today with China and the third world nations. This discourse is promoted as a justification and authorization for the spread of American hegemony over the world. On the other hand, this discourse indicates that any international contact between the two worlds is a site of collapse (Maximiliano E. Korstanje \& Geoffrey Skoll, 2015:15).
While in reality and away from fictional film, academics and experts assert that the communist China has become a military superpower and a country with rising economic growth. The scholars have coined the term "second superpower" to China because of its global and equal influence of the United States (James Wood, 2000, p. 155).

In 2004, Barry Buzan, Professor Emeritus of International Relations at the London Economics School stated that "China certainly presents the most promising all-round profile" of a superpower, asserting that "China is currently the most fashionable potential superpower and the one whose degree of alienation from the dominant international society makes it the most obvious political challenger." (Barry Buzan, 2004, p. 70).

In 2008, Parag Khanna stated that China has proven itself as a great power alongside the European Union, and the United States through its inflated share of trade in its GDP (Parag Khanna, 2014).

In 2011, Lawrence Saez, a professor in of the School of Oriental and African Studies asserted that China will overtake the United States militarily within twenty years. As for economically, Yao Yang, Director of the Chinese Center for Economic Reform at Peking University says that the renminbi will rise against the dollar by 3\% annually, and China's economy will become the largest in the world by 2021 (Thair Shaikh, 2011).

In 2012, the economist Arvind Subramanian has indicated that China will guide the global financial system by 2020 and that the Chinese renminbi will replace the dollar as the global reserve currency within 10 to 15 years. (Ted Greenwald, 2012).

In the same year, Wang Jisi the Dean of the International Studies school at Peking University., has revealed that China has become a first-class power and should be dealt with as such. China makes rapid progress in many military and economic fields while the US appears to have become a degraded superpower through many factors such as unemployment, weak economic recovery, and fiscal deficits. (Kenneth Lieberthal \& Wang Jisi, 2012).

In 2019, the Center of American Studies has presented a report indicating that Washington is no longer has a priority in the Indo-Pacific region since 9/11, to the point that China can challenge the US in the Indian and Pacific Oceans. (Ashley Townshend \& et al, 2019). 
In 2020 and after the Corona pandemic has spread, America has blamed China for trying to hide its outbreak. Foreign minister of China, Wang Yi has accused the US of attacking China repeatedly, urging it to "stop wasting time and stop wasting precious lives" in its handling with the outbreak of coronavirus. (The Ceylon Today newspaper, 2020).

From the aforementioned, it is possible to infer the reasons for the racist discourse that the film conveys to the countries of the third world represented by communist China.

\section{CONCLUSTION}

The film Contagion is a mix between possibility and probability. It narrates a story about the possibility of an apocalyptic virus to destroy humankind, and although the probability is low, its possibility existed. The film depicts in imaginary and dramatic scenes the outbreak of unknown global viruses from China destroying humankind. It predicted a decade ago a situation potentially similar to what countries experience today with the spread of the coronavirus pandemic that comes also from China. The scenes, in the film are closer to reality than to the imagination because they reflect the state of nations today and the strict measures that they take to contain the spread of the virus that can destroy the human race. Contagion shows the domination of science on a daily life, where enforced confinement and quarantine become tools for containing disease and to maintain societal order.

Contagion is a platform for spreading an ideological message to motivate politicians, doctors, and scientists to take precautions and to ignore pre-established protocols in case of a global pandemic. It conveys its ideological discourse through the narration of stereotypes, expectations, rules and ethical guidelines.

The film also conveys a racist discourse in which the third world represents the filth and underdevelopment where food handling regulations do not apply, while the advanced world represents the order and civilization. The film distorts the image of China which becomes a communist superpower that grows recently to compete with the capitalist America to control the world after the collapse of the Soviet Union.

\section{REFERENCES}

Amanda Pagan (2019). End of the World as We Know It: Apocalyptic, Post-Apocalyptic, and Dystopian Worlds. Stavros Niarchos Foundation Library (SNFL). Retrieved January 15, 2021, from https://www.nypl.org/blog/2019/12/19/ap ocalyptic-post-apocalyptic-dystopianworlds

Antoni G. Wrobel \& et al (2020). SARS-CoV-2 and bat RaTG13 spike glycoprotein structures inform on virus evolution and furin-cleavage effects. Nature Structural \& Molecular Biology, 2020; DOI: 10.1038/s41594-020-0468-7.

Ashley Townshend \& et al. (2019). Averting Crisis: American strategy, military spending and collective defence in the Indo-Pacific. United States Studies Centre (Report).

Azeez Jasim (2015). Zombies and "World War Z": Between Apocalyptic View and Reality. Al-Zahraa College for Women. Vol. 1, Issue1.

Barry Buzan (2004). The United States and the Great Powers. Cambridge, United Kingdom: Polity Press. p. 70. ISBN 07456-3375-7.

Brian Lowry (2020). The movies that predicted an outbreak like coronavirus. CNN Sans TM \& Cable News Network. A Warner Media Company. Retrieved October 18, 2020, from https://edition.cnn.com/2020/01/30/enterta inment/contagion-and-pandemics-inmovies/index.html.

Ceylon Today(2020). Tension between China and US grows. Ceylon Newspapers (PVT) LTD No. 101, Rosmead Place, Colombo 7, Sri Lanka. Retrieved October 13, 2020, from https://ceylontoday.lk/news-more/14823.

Deborah P. Dixon \& John Paul Jones (2014). The tactile topologies of Contagion. Transactions of the Institute of British Geographers published by John Wiley \& Sons Ltd on behalf of Royal Geographical Society (with The Institute of British Geographers).

Fran Kritz (2020). Fact-Checking 'Contagion' In Wake Of Coronavirus, The 2011 Movie Is Trending. Retrieved October 13, 2020, from

https://www.npr.org/sections/goatsandsod a/2020/02/16/802704825/fact-checking- 
contagion-in-wake-of-coronavirus-the-

2011-movie-is-trending.

James Berger (2000). Introduction: TwentiethCentury Apocalypse: Forecasts and Aftermaths. Vol. 46, No. 4. Duke University Press

James Wood (2000). History of International Broadcasting. IET.

John A. Cuddon (1998). Dictionary of Literary Terms and Literary Theory. Penguin Group. England, Clays Ltd, St lves plc.

Johanna Blakley \& Heesung Shin (2016). Going Viral: Measuring the Impact of Contagion. The USC Annenberg Roman Lear Center. Mead Impact Project. Retrieved October 13, 2020, from https://learcenter.org/wp-

content/uploads/2016/11/Contagion-

Report.pdf).

Kenneth Lieberthal \& Wang Jisi (2012). "US, China Experts Warn of Growing Bilateral Distrust". Voice of America. Retrieved 19 July 2014.

Kristen Rogers (2020). 'Contagion' vs. coronavirus: The film's connections to a real life pandemic. CNN Sans ${ }^{\mathrm{TM}} \&$ Cable News Network. A Warner Media Company. Retrieved October 17, 2020, from

https://edition.cnn.com/2020/04/02/movie s/contagion-movie-versus-coronavirus-scn wellness/index.html.

Martha Ross (2020). Coronavirus outbreak has people seeking answers from 'Contagion' - but it's just a movie. MediaNews Group, Inc. Retrieved October 17, 2020, from

https://www.mercurynews.com/2020/01/2 4/coronavirus-outbreak-has-peopleseeking-answers-from-contagion-but-itsjust-a-movie/.

Maximiliano E Korstanje \& Geoffrey Skoll (2011). Disasters, ethnocentrism and mobilities, exploring the Film Contagion 2011. International Journal of Safety and Security in Tourism/Hospitality. Facultad de Ciencias Económicas.

Morton D. Paley (1989) Mary Shelley's The Last Man: Apocalypse without Millennium, The Keats-Shelley Review, 4:1,125, DOI: 10.1179/ksr.1989.4.1.1.

Nicole Sperling (2020). 'Contagion,' Steven Soderbergh's 2011 Thriller, Is Climbing Up the Charts. The New York Times
Company. Retrieved October 13, 2020, from

https://www.nytimes.com/2020/03/04/busi ness/media/coronavirus-contagionmovie.html.

Norman Cohn (1999). Noah's Flood: The Genesis Story in Western Thought. Yale University Press. ISBN 978-0300076486.

Parag Khanna (2014). "Waving Goodbye to Hegemony". The New York Times.

Rachel Curtis (2012). Tsunami Survivor's Impossible Story Hits the Big Screen. BBC News. Retrieved January 15, 2021, from

https://www.bbc.com/news/entertainmentarts-20783441

Richard A. Taylor \& David M. Howard Jr. (2016). Interpreting Apocalyptic Literature: An Exegetical Handbook. Kregel Publications, a division of Kregel, Inc., 2450 Oak Industrial Dr NE, Grand Rapids, MI 49505-6020. United States of America

Ted Greenwald (2012). "Taming the Dragon: One Scholar's Plan to Soften Chinese Dominance". WIRED. 20 (3).

Retrieved June 28, 2014.

Thair Shaikh (2011). "When Will China Become a Global Superpower?". CNN. Archived from the original on 11 March 2012. Retrieved 28 June 2014.

The Noble Quran (2016). Available at https://quran.com/?local=en. Retrieved 15 October, 2020.

Valerie P. Zimbaro (1996). Encyclopedia of Apocalyptic Literature. US: ABC-CLIO. p. 9. ISBN 0-87436-823-5.

World Health Organization (2020). Coronavirus disease (COVID-19) pandemic. Retrieved October 18, 2020, from https://www.who.int/emergencies/diseases Inovel-coronavirus 019?gclid=EAIaIQobChMI26Hz54S_7AI VJgZ7Ch0JFg2mEAAYASAAEgLOu_D_ BwE.

Zi-Wei Ye, et al (2020). Zoonotic origins of human coronaviruses. International journal of biological sciences, 16(10), 1686-1697.

https://doi.org/10.7150/ijbs.45472.

Retrieved October 17, 2020, from https://www.ncbi.nlm.nih.gov/pmc/article s/PMC7098031/. 
يـوخته

فيلمى (قهُر) contagion (2011) ز قه هاندا هزريّ بو بهلاق بوونا ثايروسا MEV-1 يا ثه گرا جيهانى. فيلم دبيّزيت بارودوخهكي وهك رويدانيّت فيّ دوماهي يه بهر بهلاث بوونا يهتايا قايروسا كرونايى. ئامانج: ئهق ثهكولينه دياردكهت جهوانيا دياربوونا فيلمى Contagion ب شيّوهكي ترسناك بو في يُيشا جيهانى Covid-19 زبهرى جهنديين ساليّن بورين. جهوانيا ههولدانا جيّكهرين فلمى بو نيشاندانا ويّنهى نزيكى رويدانيّت ئه قرو دگهل هزرا. دهامن دهورا دشياندايه قهكولين تيشكين روناهي ب دانته سهر گوتهرىّ سياسى توخوم يهرستى فيلمى ئهوى وينى جيهانى يـى سى ئهويّن نونهريا زل هيّا. جينا شيوعى د جيهانها جياواز و دكتاتورى و ترسناك براورد دگهل جيهانا ئيّىى ئهوا نوينهراتيا ئهمريكا رهئسمالى كه جيهانهكا ئاقاكهر و ديموكراتى و سلامهتى. مهرجئ فيلمي Contagion كو بازركانيا

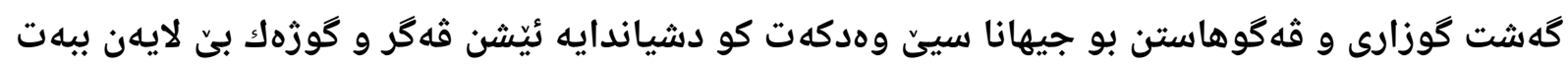
بهلام سلامهتى بهس دناقبهرا دهوله تيّن جيهانا ئيّكى يه. ئهنجام: دابهشكرنا قه كولييّن ل سهر سىّ تهوهرا يـ ئيّكى قهكولينهكا كورت ل سهر جهوانيا بوماهيك ئينا جيهانى و يشتى دوماهيك ئينا وىّ. بهشى دوى تيشكى دهته سهر فيلمى Contagion بو گوتنا يِيش

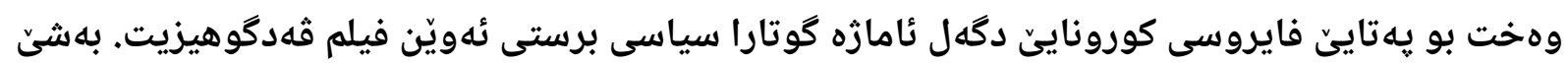
سى دوماهيك ئينانا ثهولينى بيشكيّدكهت، ئه فه كولينه دهيّته دوماهيك ئينان ب ليستها زيّدهرا زيدهبارى كورتيهكا ب هلردوو زمانيّن كوردى و عهرهبى. دهرئهنجام: ئه فيلمى هه ديار دكهت ويلايهتيّن ئيك كرتى ئه مريكا ز هيزهكا مهزن دجيهانا ئيكى دا بو مايتيّكرن بو ياراستنا ثٔاسايشا تهندروستى يا جيهانى ب ريكا كونترول كرنا بازركانى و ثه گوهاستنى و دابه شكرنا خوراكى. 
فيلم ( العدوى) Contagion (2011) هو سرد خيالي لانتشار فيروس MEV-1 الوبائي العالمي. يحاكي الفيلم وضعًا يحتمل أن يكون مشابها للأحداث الأخيرة لتفشي جائحة فيروس كورونا. تهدف الدراسة إلى الكشف عن كيفية توقع فيلم Contagion بشكل مخيف للوباء العالمي 19 COVID منذ ما يقرب من عقد من الزمان, وكيف يحاول صناع الفلم قدر الإمكان تصوير مشاهد أقرب إلى الواقع منه الى الخيال. كما تهدف الدراسة ايضا الى تسلط الضوء على الخطاب السياسي العنصري للفيلم الذي يصور العالم الثالث الذي تمثله القوة العظمى الشيوعية, الصين كعالم متخلف وديكتاتوري وخطير مقارنة بالعالم الأول الذي تمثله القوى العظمى الرأسمالية, أمريكا كعالم من التنمية والديمقراطية والسلامة. يفترض فيلم Contagion السلامة تكمن فقط في الانتقال بين دول العالم الأول. تنقسم الدراسة إلى ثلاثة أقسام. يقدم القسم الأول دراسة موجزة عن رواية نهاية العالم وما بعد النهاية. يلقي القسم الثاني الضوء على فيلم Contagion كتنبؤ لوباء فيروس كورونا مع الإشارة إلى الخطاب السياسي العنصري الذي ينقله الفيلم. يقدم القسم الثالث استنتاجا مفاده أن احتمالية ظهور وباء يقضي على الجنس البشري وارد على الرغم من ضعفه ، وان الغرض من وراء تصوير الصين كمكان موبوء هو بمثابة تفويض لامريكا بالتدخل للحفاظ على الأمن الصحي العالمي من خلال تقييد التجارة والتنقل وتوزيع الغذاء. تنتهي هذه الدراسة بقائمة من المراجع بالاضافة الى الخلاصة باللغتين الكوردية والعربية. 